\title{
A case of positive pregnancy test in a sexually inactive solid organ transplant recipient - can human chorionic gonadotropin be transmitted through solid organ transplantation?
}

\author{
Mina Al-Badri*1, Kunam Reddy ${ }^{2}$, Paru David $^{1}$, Raymond Heilman ${ }^{3}$, Christine Snozek ${ }^{4}$, Suneela Vegunta ${ }^{1}$ \\ ${ }^{1}$ Women Health Internal Medicine, Mayo Clinic, Scottsdale, AZ, USA \\ ${ }^{2}$ Transplantation, Mayo Clinic, Phoenix, AZ, USA \\ ${ }^{3}$ Nephrology, Mayo Clinic, Phoenix, AZ, USA \\ ${ }^{4}$ Division of laboratory Medicine, Mayo Clinic, Scottsdale, AZ, USA
}

Received: April 24, 2016

DOI: $10.5430 /$ crim.v3n4p4
Accepted: May 18, 2016

Online Published: August 1, 2016

\begin{abstract}
A twenty one year old female with end stage renal disease underwent a non-related renal transplantation from a deceased pregnant donor. The recipient had a negative serum pregnancy test prior to her surgery. However postoperatively, a rise in her serum human chorionic gonadotrophin (hCG) level, which lasted several days, was documented. Solid organ transplantation is known to transmit various infections, malignant cells and antibodies from donor to recipient but no previous reports described transmission of hCG. This case report highlights the importance of considering this possibility when managing post-transplantation hormonal disturbances. Further research is warranted to evaluate the different mechanisms through which transmission occurs between donor and recipient.
\end{abstract}

Key Words: Human chorionic gonadotropin, Kidney transplantation, Pregnant donor

\section{INTRODUCTION}

Elevated human chorionic gonadotropin (hCG) can be found in both pregnant and non-pregnant women with end stage renal disease (ESRD) ${ }^{[1]}$ In non-pregnant women, this elevation can be attributed to various causes that are well described. These include reduced renal excretion of hCG, false positive results from interfering antibodies, pituitary hCG secretion in post-menopausal women, secretion from trophoblastic tumors and exogenous administration. ${ }^{[2,3]}$ However, with our case report, we identified another cause to this differential diagnosis.

\section{CASE PRESENTATion}

A 21-year-old white female was seen in our clinic for contraceptive counseling after her recent kidney transplantation. Her past medical history is significant for Systemic Lupus Erythematosus (SLE) with biopsy proven focal proliferative glomerulonephritis leading to ESRD and peritoneal dialysis. Her last menstrual cycle started on the same day of her kidney transplantation surgery. Her menarche was at age

*Correspondence: Mina Al-Badri; Email: minaalbadri@gmail.com; Address: 13737 N 92 nd street, Scottsdale, AZ 85260, USA. 
13. She has never been sexually active and has not used any contraceptive methods. She completed a preoperative Pap smear, which was negative for malignancy. Birth control options were discussed but not initiated at that time. Her routine preoperative pregnancy test, quantitative serum hCG was negative $(<0.5 \mathrm{mIU} / \mathrm{ml})$ on the day of surgery.

She underwent a non-related renal transplant from a deceased pregnant woman, who died of intracranial hemorrhage in a motor vehicle accident. The donor was healthy and at 22 weeks of gestation (hCG level is unavailable). Fetal demise was reported and retained in the uterus. The donor had acute kidney injury with admitting creatinine of $0.9 \mathrm{mg} / \mathrm{dl}$ and terminal creatinine of $7.0 \mathrm{mg} / \mathrm{dl}$ before procurement. Nevertheless her kidney biopsy was normal except for acute tubular injury.

On postoperative day three, patient had a routine pregnancy test completed and this was found to be positive. Her serum hCG was elevated at $43.7 \mathrm{mIU} / \mathrm{ml}$. But serial, consecutive measurements revealed gradually falling levels of hCG over the next 72 hours $(32.1,20.2,16.1 \mathrm{mlU} / \mathrm{ml})$. No urine $\mathrm{hCG}$ testing was performed. Following her transplant, she had delayed graft function requiring dialysis for 2 weeks. Her hCG level was rechecked three months after the transplantation and was negative $(<0.5 \mathrm{mIU} / \mathrm{ml})$. Currently 6 months post-transplant, she is doing well with excellent renal graft function (serum creatinine $1.0 \mathrm{mg} / \mathrm{dl}$, estimated GFR $>60$ $\mathrm{ml} / \mathrm{min})$.

\section{DISCUSSION}

hCG is a heterodimeric glycoprotein hormone, which consists of alpha and beta subunits. The serum and urine concentrations of hCG rise significantly early in pregnancy, doubling every 48 hours, until reaching its peak around 10 weeks of gestation. In fact, serum concentrations of hCG vary widely within the first 4 weeks of gestation. However, a serum concentration of hCG above $25 \mathrm{mIU} / \mathrm{ml}$ can diagnose conception. At the 2 nd trimester of pregnancy, the level of hCG usually ranges from 3,000-50,000 $\mathrm{mIU} / \mathrm{ml}$, while a concentration in the range of $30-40 \mathrm{mIU} / \mathrm{ml}$ is more consistent with an intact pregnancy of 3-5 weeks duration. ${ }^{[4]}$

Beta hCG has a reported half-life of 24-36 hours. Quantitative serum hCG was measured using the Roche Elecsys hCG STAT reagent on a Cobas e601. The electrochemilumenescence immunoassay uses two monoclonal antibodies to specifically detect the hCG holo-enzyme, for use in diagnosis and monitoring of pregnancy. The lowest reportable value is $0.5 \mathrm{mIU} / \mathrm{ml}$. Precision of the assay (coefficient of variation) is typically $5 \%-7 \%$ for the low and medium controls (approximately $5 \mathrm{mIU} / \mathrm{ml}$ and $20 \mathrm{mIU} / \mathrm{ml}$, respectively).

Published by Sciedu Press
Per the manufacturer's package insert, expected values for non-pregnant, pre-menopausal women are $\leq 1 \mathrm{mIU} / \mathrm{ml}$ (upper $95 \%$ confidence limit, $\leq 4.9 \mathrm{mIU} / \mathrm{ml}$ ); expected median values in pregnancy range from $18.7 \mathrm{mIU} / \mathrm{ml}$ in week 3 up to $104,475 \mathrm{mIU} / \mathrm{ml}$ in week 9 .

With a previously negative hCG test on the day of surgery, the transient elevation of hCG in the serum of our patient, suggests that it had most likely transferred through the donor's kidney tissue or blood during transplantation. The passive transfer of the hCG hormone by red blood cell transfusion from a pregnant donor was previously reported. ${ }^{[5]}$ However during the recovery of a deceased donor graft, cold irrigate is used to preserve the organ during transfer. Ideal preservation solution contains impermeant molecules that suppress hypothermia induced cell swelling and retard the accumulation of water inside the cells. During the graft preparation, donor blood is irrigated outside the kidney. ${ }^{[6,7]}$ Whether other active substances, such as hCG are transferred through the cell wall in this osmotically inactive environment is not known. This may suggest that the detected hCG levels in the recipient happened secondary to tissue transfer. It gradually permeated to the recipient's blood and was detectable later on.

Several products and infections are documented to transfer during solid organ transplantation. The exact mechanism through which they are transferred from donor to recipient is not clear. Moreover, there is a $0.2 \%$ risk of transmitting donor malignant tumor cells to the recipient. ${ }^{[8]}$ This is believed to happen through transplant of the involved organ (or its surrounding tissue), transfer of circulating malignant cells, or through blood vessel invasion. ${ }^{[9]}$ The transmission of infection, on the other hand, can happen through viable cells (or tissues), blood, hematopoietic stem cells, or vascularized organs. ${ }^{[10]}$ The passive transfer of hepatitis B antibodies from the vaccinated donor, to the recipient is well documented. ${ }^{[11]}$ In addition, one case series documented chimerism of five renal allograft recipients who underwent transplantation 27 to 29 years before, suggested the possibility of transferring hematopoietic stem cells through the interstitium of the transplanted kidneys to the recipients. ${ }^{[12]}$ In our case, the recipient of the sister kidney from the same donor is a postmenopausal female. On the day of her surgery, hCG level was checked and found to be normal $(4.3 \mathrm{mIU} / \mathrm{ml})$. Subsequently on postoperative day 5 , the level had risen to $13.3 \mathrm{mIU} / \mathrm{ml}$ and two weeks postoperatively the levels gradually declined to normal. Her renal function stayed around its preoperative level for several days. This steadily improved to normal levels after few weeks. Collectively this may confirm that the origin of hCG is from the donor and not from the recipient. 


\section{Conclusion}

To our knowledge, this is one of the first case reports of transmission of the pregnancy hormone hCG from a solid organ donor to the recipient. This case highlights the importance of exercising caution when interpreting blood test results of solid organ recipients. Some of the test results are affected by their recent transplantation. The various mecha- nisms through which infections, malignant cells, antibodies and intact hormones are transmitted from donor to recipient are still ambiguous. More research is needed in this area, which will help with the prophylactic measures taken by the transplant teams.

\section{CONFlicts OF INTEREST Disclosure}

The authors have declared no conflicts of interest.

\section{REFERENCES}

[1] Potluri K, Moldenhauer J, Karlman R. Beta HCG levels in a pregnant dialysis patient: a cautionary tale. NDT Plus. 2011; 4: 42-43 http://dx.doi.org/10.1093/ndtplus/sfq195

[2] Marcillac I, Troalen F, Bidart JM, et al. Free human chorionic gonadotropin beta subunit in gonadal and nongonadal neoplasms. Cancer Research. 1992; 52(14): 3901-7. PMid:1377600

[3] Delbeke FT, Van Eenoo P, De Backer P. Detection of human chorionic gonadotrophin misuse in sports. International Journal of Sports Medicine. 1998; 19(4): 287-90. PMid:9657371 http://dx.doi.o $\mathrm{rg} / 10.1055 / \mathrm{s}-2007-971920$

[4] Fahy BG, Gouzd VA, Atallah JN. Pregnancy tests with end-stage renal disease. Journal of Clinical Anesthesia. 2008; 20(8): 60913. PMid:19100935 http://dx.doi.org/10.1016/j.jclinan e. 2008.05 .025

[5] Shelat SG, Friedman DF, Meny GM, et al. False-positive pregnancy test after passive transfusion of beta-human chorionic gonadotropin from donor red blood cells during erythrocytapheresis. Transfusion. 2007; 47(5): 788-91. PMid:17465942 http://dx.doi.org/10. $1111 / j .1537-2995.2007 .01191 . x$

[6] Groenewoud AF, Thorogood J. A preliminary report of the HTK randomized multicenter study comparing kidney graft preservation with HTK and EuroCollins solutions. HTK Study Group. Transplant international: Official Journal of the European Society for Organ Transplantation. 1992; 5 Suppl 1: S429-32.
[7] Faenza A, Catena F, Nardo B, et al. Kidney preservation with university of Wisconsin and Celsior solution: a prospective multicenter randomized study. Transplantation. 2001; 72(7): 1274-7. PMid:11602855 http: //dx .doi.org/10.1097/00007890-200 110150-00016

[8] Birkeland SA, Storm HH. Risk for tumor and other disease transmission by transplantation: a population-based study of unrecognized malignancies and other diseases in organ donors. Transplantation. 2002; 74(10): 1409-13. http://dx.doi.org/10.1097/0000789 0-200211270-00012

[9] Braun-Parvez L, Charlin E, Caillard S, et al. Gestational choriocarcinoma transmission following multiorgan donation. American Journal of Transplantation: Official Journal of the American Society of Transplantation and the American Society of Transplant Surgeons. 2010; 10(11): 2541-6. PMid:20977645 http://dx.doi.org/10.1111 /j.1600-6143.2010.03275.x

[10] Fishman JA. Infection in solid-organ transplant recipients. The New England Journal of Medicine. 2007; 357(25): 2601-14. PMid:18094380 http://dx.doi.org/10.1056/NEJMra064928

[11] Shouval D, Adler R, Ilan Y. Adoptive transfer of immunity to hepatitis $\mathrm{B}$ virus in mice by bone marrow transplantation from immune donors. Hepatology. 1993; 17(6): 955-9. PMid:8514268 http://dx.doi.org/10.1002/hep.1840170602

[12] Starzl TE, Demetris AJ, Trucco M, et al. Chimerism and donorspecific nonreactivity 27 to 29 years after kidney allotransplantation. Transplantation. 1993; 55(6): 1272-7. PMid:8516813 http: //dx.doi.org/10.1097/00007890-199306000-00012 